\title{
Speleothem and biofilm formation in a granite/dolerite cave, Northern Sweden
}

\author{
Therese Sallstedt ${ }^{1,2 *}$, Magnus Ivarsson ${ }^{1,2}$, Johannes Lundberg ${ }^{3}$, Rabbe Sjöberg ${ }^{4}$, and \\ Juan Ramón Vidal Romani ${ }^{5}$ \\ ${ }^{1}$ Nordic Center for Earth Evolution (NordCEE) and Department of Biology, University of Southern Denmark, DK-5230 Odense, Denmark \\ ${ }^{2}$ Swedish Museum of Natural History, Department of Paleobiology, SE-104 05 Stockholm, Sweden \\ ${ }^{3}$ Swedish Museum of Natural History, Department of Botany, SE-104 05 Stockholm, Sweden \\ ${ }^{4}$ Bodviksvägen 14, SE-913 42 Obbola, Sweden \\ ${ }^{5}$ University of Coruña, Campus de Elviña, ES-15071 Coruña, Spain
}

\begin{abstract}
Tjuv-Antes grotta (Tjuv-Ante's Cave) located in northern Sweden is a round-abraded sea cave ('tunnel cave'), about $30 \mathrm{~m}$ in length, formed by rock-water abrasion in a dolerite dyke in granite gneiss. Abundant speleothems are restricted to the inner, mafic parts of the cave and absent on granite parts. The speleothems are of two types: cylindrical (coralloid, popcorn-like), and flowstone (thin crusts). Coralloids correspond to terrestrial stromatolite speleothems in which layers of light calcite alternate with dark, silica-rich laminae. The dark laminae are also enriched in carbon and contain incorporated remains of microorganisms. Two types of microbial communities can be distinguished associated with the speleothems: an Actinobacteria-like biofilm and a fungal community. Actinobacteria seem to play an important role in the formation of speleothem while the fungal community acts as both a constructive and a destructive agent. A modern biofilm dominated by Actinobacteria is present in the speleothem-free parts of the dolerite and located in cave ceiling cracks. These biofilms may represent sites of early speleothem formation. Because of its unusual position in between two types of host rock, Tjuv-Ante's Cave represents a unique environment in which to study differences in microbe-rock interactions and speleothem genesis between the granite and dolerite host rock. Our study shows that the mafic rock is superior to the granite in hosting a microbial community and to support formation of speleothems.
\end{abstract}

Keywords: biospeleothem; Actinobacteria; lamination; pseudokarst; sequestration of $\mathrm{CO}_{2}$

Received 27 November 2013; Revised 28 March 2014; Accepted 21 June 2014

Citation: Sallstedt T., Ivarsson M., Lundberg J., Sjöberg R. and Vidal Romaní J.R., 2014. Speleothem and biofilm formation in a granite/dolerite cave, Northern Sweden. International Journal of Speleology, 43 (3), 305-313. Tampa, FL (USA), ISSN 0392-6672 http://dx.doi.org/10.5038/1827-806X.43.3.7

\section{INTRODUCTION}

The formation of authigenic minerals, which are deposited as speleothems in caves, is controlled by hydrodynamical conditions such as fluid flow and saturation, as well as geochemical conditions like redox, $\mathrm{pH}$ and host rock composition. One parameter that is still unclear is the degree and nature of microbial involvement in speleothem formation (Barton et al., 2001; Barton \& Northup, 2007). Speleothems are usually associated with active or encrusted microorganisms. Speleothem microbiota can be highly varied, containing bacteria, fungi, algae, testate amoeba, collembolan and mites among other organisms (Vidal Romani et al., 2013). However, the question remains whether the microorganisms are actively involved in the formation or simply buried during mineral precipitation. Microorganisms play an important role in accretion of microbial mineral deposits. In addition to trapping and binding of sediments, they can also actively promote mineral growth through biogeochemical pathways associated with their metabolism, for example through excretion of hydroxyl ions during photosynthesis, which increase alkalinity and promote calcite growth (Arp et al., 1999a, 1999b; Arp et al., 2001). Bacteria using other metabolic pathways such as heterotrophic sulphate reducing bacteria (SRB's) or Actinobacteria have also been known to affect the alkalinity of their microenvironment and therefore induce mineral precipitation in both stromatolites and various kinds of cave deposits (Braissant et al., 2007; Curry et al., 2009; Braissant et al., 2012). In many cases, microbes and their extracellular polymeric substances, EPS, act as effective nucleation substrates, which can lead to a passive encrustation of biofilm communities that 
influence the fabrics of the speleothems. However, EPS and their negatively charged functional groups, appear to play a dual role in mineral precipitation. At first, the EPS can act as a cation sink which may inhibit mineral precipitation until this sink either has been surpassed due to very high concentrations of for example mineralforming $\mathrm{Ca}^{2+}$ or $\mathrm{Mg}^{2+}$ ions in the ambient water, or until sufficient degradation of the EPS by heterotrophic bacteria has occurred to release some of the trapped divalent cations back into the water (see for example Dupraz \& Visscher, 2005; Dupraz et al., 2009). Some microorganisms, especially fungi, are also known to act as mineral destructive agents, primarily through chemical etching and physical breakdown of the substrates (e.g., Jones, 2001).

The most fundamental parameter that influences the mineralogy of speleothems is the type of rock in which the cave is hosted. Since speleothem formation is influenced by infiltrating rain or groundwaters that have passed through the rock, its composition naturally reflects the composition of the host rock. Karstic caves in limestones, for example, are usually characterized by calcite speleothems. In granitic caves, speleothems are fairly common (Vidal Romani et al., 2010) and although many different speleothemforming minerals have been identified (for example evansite, bolivarite, struvite, pigotite, taranakite, allophane, hematite, goethite, halite, gypsum, anhydrite, plumbo-aragonite and even calcite), the most common authigenic mineral of speleothems in granitic caves is opal-A, an amorphous hydrated polymorph of silica (Vidal Romaní et al., 2013). Although calcite has not been reported as a major speleothem forming mineral from granitic caves before, many studies (e.g., Woo et al., 2008; Baskar et al., 2009; Gysi \& Stefánsson 2012a, 2012b; Hövelmann et al., 2012; Oskierski, 2013; Schwarzenbach et al., 2013; Van Noort et al., 2013) mention the existence of calcite in caves developed in plutonic or volcanic magmatic rocks such as granodiorites, peridotites, serpentinites and basalts. In lava caves hosted in mafic volcanic rocks, speleothems are frequently formed by precipitation of opal-A and calcite as well as other minerals like oxides and sulfides (Woo et al., 2008; Baskar et al. 2009; White, 2010).

Tjuv-Ante's Cave in Västerbotten County, northern Sweden, is developed by marine erosion in a dolerite dyke intruded in granite gneiss; therefore, the cave walls are of granite and the ceiling of dolerite. This makes it an excellent site to compare geochemistry, speleothem formation and microbial colonization between the different types of host rock. To our knowledge, a combined granite and dolerite cave like Tjuv-Ante's Cave has not been previously described in a geomicrobiologic context.

\section{SAMPLES AND METHODS}

\section{Tjuv-Ante's Cave}

Tjuv-Ante's Cave is situated at an elevation of 90 metres above sea level in Storrisberget's Nature Reserve on the north-eastern Swedish coast at $\mathrm{N} 63^{\circ}$ $35.6^{\prime}, \mathrm{E} 19^{\circ} 22.8^{\prime}$. The cave is formed along a dolerite dyke in granite gneiss. The length of the cave forming crevice is about $30 \mathrm{~m}$, with a width of approximately 0.5 to $1.5 \mathrm{~m}$ (Fig. 1A). The inner part of the crevice has a dolerite ceiling, forming a dark zone, while the outer part is open (Fig. 1A). The outer part of Tjuv-Ante's Cave is filled with dolerite boulders from collapsed ceiling (Fig. 1A and 1B). The crevice with the cave shows signs of abrasion, forming a round-abraded sea-cave (tunnel cave sensu Sjöberg, 1994) with rounded boulders found in the inner part (Fig. 1A). The abrasion of the crevice, and thus the origin of the cave, was initiated around 8,000 years BP when the shoreline was at the level of the higher parts of the crevice due to the eustatic uplift following the Weichselian glaciation (Berglund, 2012). The abrasion continued until about 6,500 years BP when the crevice with the cave was raised too high above sea level to be modified by high energetic waves (Sjöberg, 1982).

Tjuv-Ante's Cave lies in the cold temperate zone, but near the subarctic, with a climate characterized by large temperature variations. The January mean temperature is about $-10^{\circ} \mathrm{C}$, while the July mean temperature is around $+15^{\circ} \mathrm{C}$. The yearly mean temperature is close to $+5^{\circ} \mathrm{C}$. The mean precipitation is $700 \mathrm{~mm} /$ year, with about $35 \%$ of the precipitation as snow (SMHI, 2012).

\section{Samples}

Four samples of $1 \mathrm{x} 1 \mathrm{~cm}$ were collected from various locations in the speleothem (see Fig. 1A). Sampling sites were selected with respect to variations in speleothem morphology, presence and absence of biofilms and to avoid visible damage. Efforts were made to avoid introduction of extraneous contamination. The samples were contained in aluminum foil after sampling and they have only been treated with stainless steel forceps and not touched by ungloved hands. The speleothems and associated microbial structures were studied by a combination of optical microscopy and Environmental Scanning Electron Microscope (ESEM) coupled with Energy Dispersive Spectrometry (EDS). $\delta^{13} \mathrm{C}$ analysis was also performed on two speleothem samples.

A modern biofilm that was not directly associated with the speleothem but found concentrated in cracks in the dolerite ceiling, was sampled with stainless steel forceps. The samples were instantly placed in glass bottles and frozen and only extracted for analysis with optical microscopy, ESEM/EDS and staining with the dye DyLight 488 NHS ester under fluorescent microscopy. Optical microscopy was performed on fresh biofilm and vertical and horizontal polished speleothem sections (some samples were infused in a clear epoxy), using a NIKON SMZ-1000 Stereomicroscope and an Olympus BX51 microscope with an Olympus DP71 camera.

The ESEM analyses were performed at the Department of Geological Sciences, Stockholm University using a Philips XL 30 ESEM-FEG, which is a field emission microscope. EDS analyses were performed using an Oxford x-act Energy Dispersive Spectrometer (EDS). The samples were subjected to a pressure of 0.5 torr and the accelerating voltage 

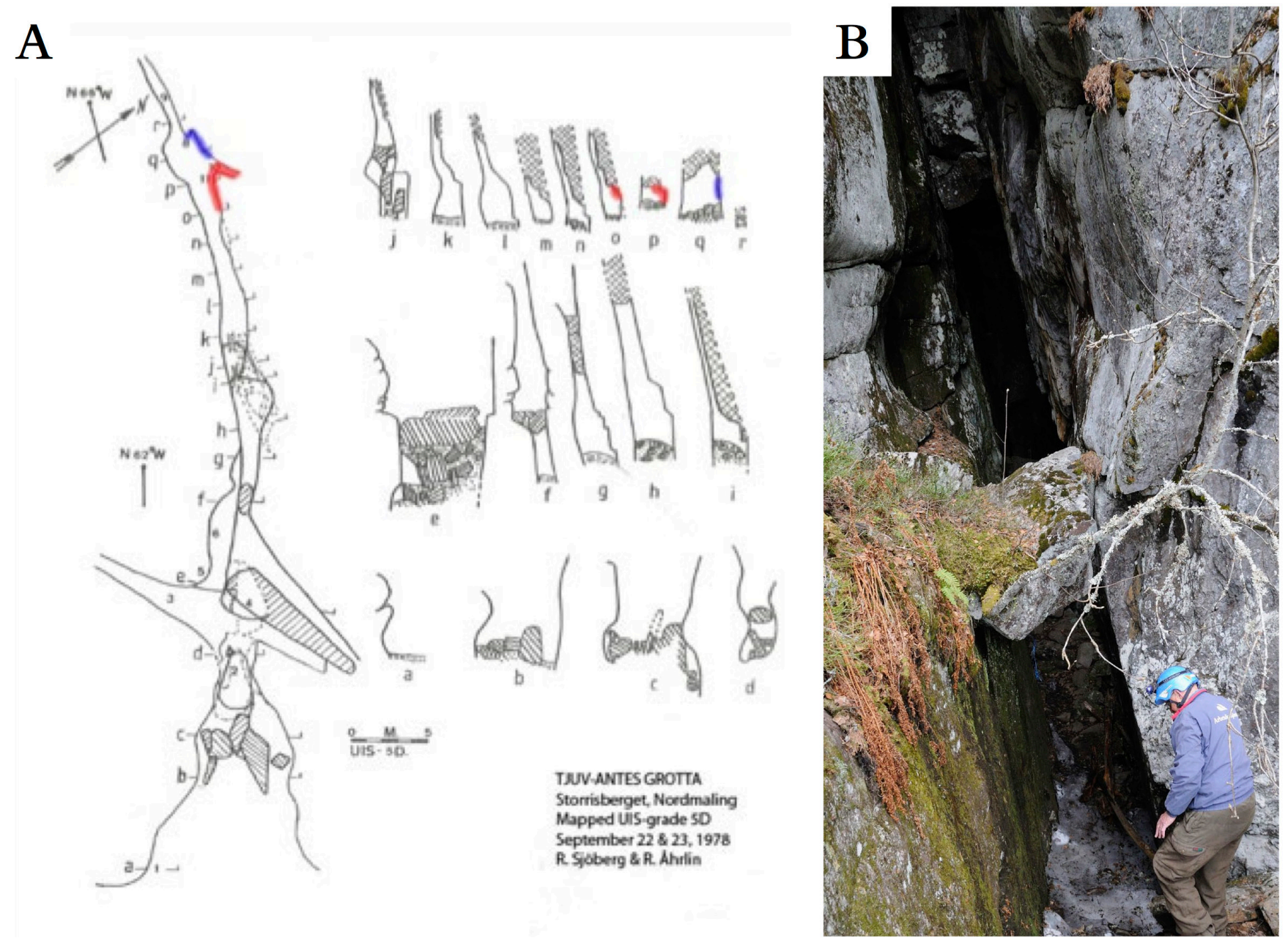

Fig. 1. Profile map of Tjuv-Ante's Cave (Tjuv-Antes grotta) (A) where red indicates sampled speleothems and blue indicate sampled cave wall biofilm. (B) Tjuv-Ante's Cave as seen from the outside, looking in. Boulders block part of the cave crevice.

was 15 or $20 \mathrm{kV}$ depending on the nature of the sample. The instrument was calibrated with a cobalt standard, and peak and element analyses were made using INCA Suite 4.11 software.

For SEM observations, the samples were prepared at the Institute of Geology, University of Coruña, according to standard protocol. This includes desiccation through storage in a hermetic desiccator of silica gel for one week, to avoid the production of artifacts, especially polygonal cracking of the amorphous opal layers. Once desiccated, the samples were coated by sputtering with a thin gold layer of 50-100 A, using the catodic pulverization equipment BAL-TEC SCD 004. Carbon sputtering was not used because of potential masking of the carbon content in organic parts of the samples. The samples were studied under a JEOL JSM 6400 Scanning Electron Microscope.

After examination of the speleothems under binocular magnifying lenses, samples of calcium carbonate crystals were separated and sent to the AMS Tandem Laboratory of Uppsala (Sweden) for dating. No special treatment of these samples was necessary.

\section{Stable isotopes $\delta^{13} \mathrm{C}$}

For stable isotope analysis, the samples were combusted with a Carlo Erba NC2500 analyser connected via a split interface to reduce the gas volume to a Finnigan MAT Delta V mass spectrometer.
From these measurements the reproducibility was calculated to be better than $0.15 \%$ for $\delta^{13} \mathrm{C}$. The relative error was $<1 \%$ for the measurements.

\section{RESULTS}

\section{The speleothem}

The speleothems in Tjuv-Ante's Cave can be divided into three categories based on morphology: coral-like, popcorn-like (cylindrical speleothems) and thin crusts (flowstone):

(i) Coral-like speleothems consists of globular calcite cemented into elongated finger-shaped coralloids (Fig. 2A-C), approximately 1-4 cm long. The coralloids grow actively on the cave wall and ceiling (Fig. 2A), and they are often covered in a graded dark brownblack biofilm (Fig. 2B-C). The coralloids grow in dense groups and are abundant in the cave. Studies of the coralloid microfabric using ESEM reveal that the primary fabric in actively accreting areas consist of mainly acicular calcite crystals together with some euhedral, blocky calcite (Fig. 2D-E).

(ii) Smooth rounded, popcorn-like speleothems grow on the dolerite cave walls in proximity to the coral speleothems (Fig. 3A). Morphologically, these are similar to the coral-like speleothems but are generally more rounded. Spherical protrusions extend from an overall smooth calcite stem, resembling a popcornlike morphology (Fig. 3B-D). 

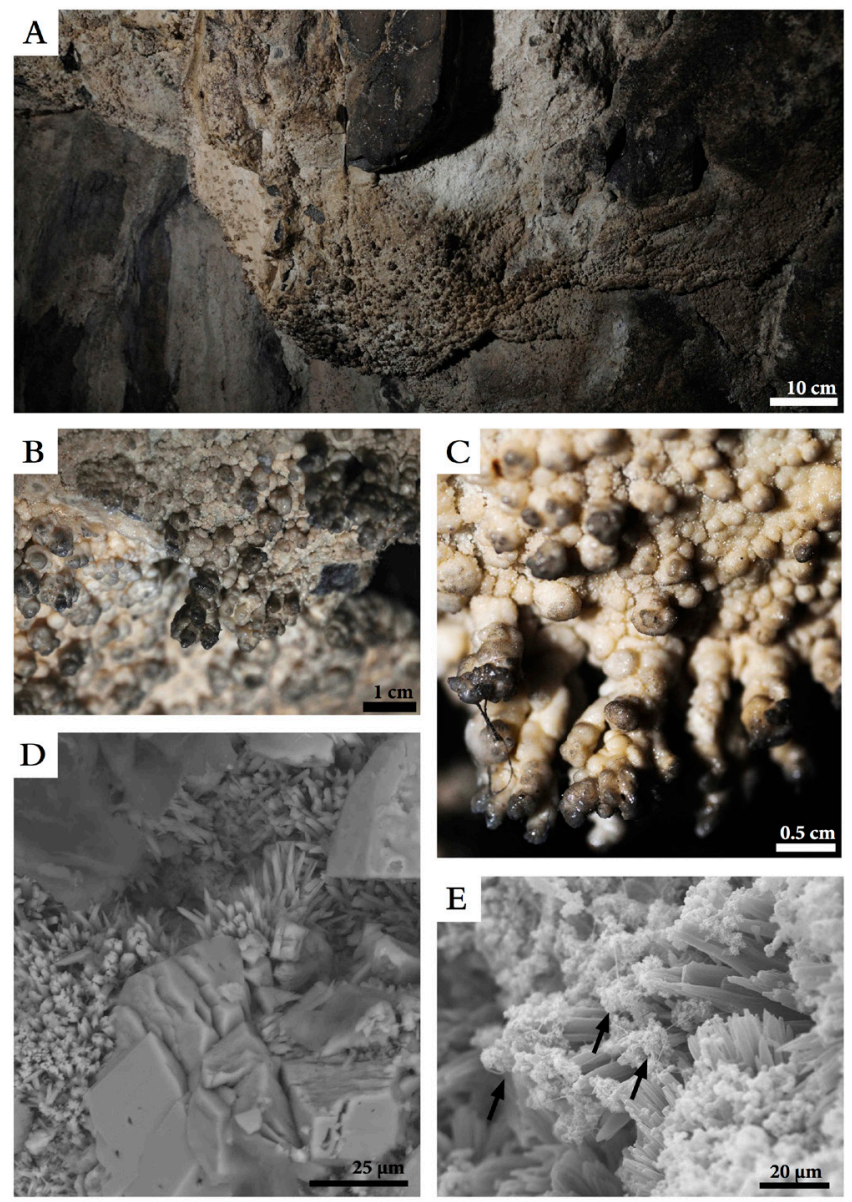

Fig. 2. Abundant coral speleothem growing on the dolerite part of Tjuv-Ante's Cave (A). Close-up of coralloids extended from the cave ceiling. Note the dark biofilm that covers the tip of the coralloids (B-C). Photomicrographs showing the calcite matrix of cora speleothems, which consist of acicular calcite crystals together with some euhedral calcite (D-E). Note how groups of coccoidal structures are concentrated on the tip of acicular calcite crystals (arrow, Fig. 3E).

(iii) Smooth calcite crusts (flowstone) resemble a highly eroded version of the coralloid speleothems and often exhibit small, evenly polished, protrusions (Fig. 3E). They are commonly covered in dark biofilms and appear moister than the other two types.

All speleothems grow exclusively from the dolerite area of Tjuv-Ante's Cave. Microfabric analyses reveal that the speleothems have accreted in cycles, as shown by more or less concentric and stromatolitelike laminations visible in cross sectional speleothem fragments (Fig. 4A). The laminae consist of alternating dark and lighter layers, which can be distinguished on the basis of elemental composition as well as morphological variations between crystals and the general matrix (Fig. 4B). As opposed to the almost pure calcite found among the lighter laminae, the dark laminations have high silica contents (up to approximately $20 \mathrm{wt} \%$ ), which are usually accompanied by high (up to 7-15 wt\%) Mg-levels. The dark areas are also characterized by high carbon contents. The high carbon contents in these areas are hypothesized to reflect the former presence and mineralization of organic rich biofilms, which is further supported by the presence of incorporated coccoidal and filamentous structures, and carbonrich EPS-like films associated with the darker areas (see section on speleothem microbiology).

\section{C14 dating}

A sample of the speleothems was dated by $\mathrm{C} 14$ at the Ångström Laboratory in Uppsala, Sweden, to $1259 \pm 30$ years B.P.

\section{Speleothem microbiology}

There are mainly two different types of biofilm associated with the coralloid speleothems: a recent mycelium-like community that covers large areas around the top of growing coralloids, and a biofilm dominated by small filaments and spore-like coccoids in an EPS matrix (see Fig. 5A-G):

\section{Speleothem biofilm}

The biofilm is characterized by incorporated and protruding filaments, $\sim 1 \mu \mathrm{m}$ in diameter and approximately $10 \mu \mathrm{m}$ in length. The filaments are regularly septated and branch frequently (Fig. 5A and B, arrows). Helically coiled loops of filaments are also present in these types of biofilms, which are found in actively accreting areas of the coralloid speleothems (Fig. 5C).

The coccoid structures are about 1-2 $\mu \mathrm{m}$ in diameter and are found in assemblages of hundred or more (Fig. 5D-E). The coccoids appear to be calcified and are covered with acicular calcite crystals (e.g., Fig. 5F$\mathrm{G})$, but smooth, uncovered coccoids occur as well. The
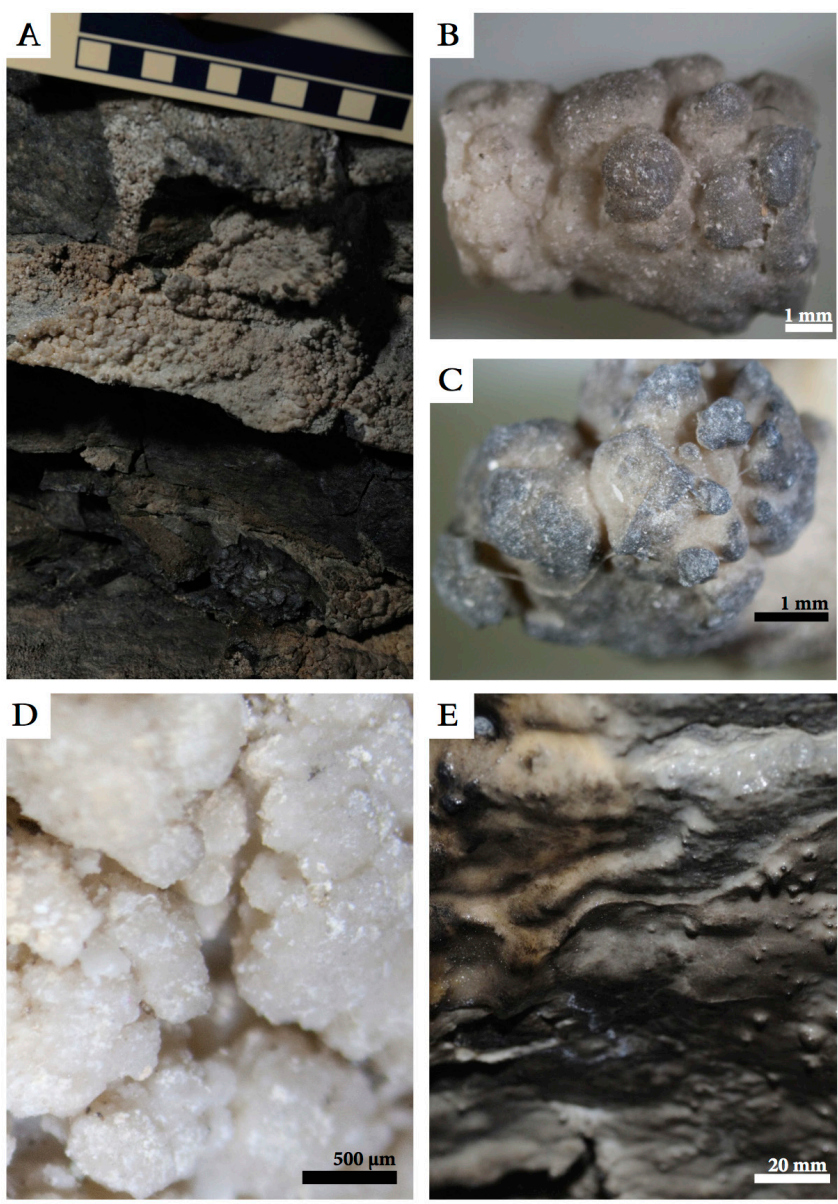

Fig. 3. Popcorn-like speleothem on the dolerite wall of Tjuv-Ante's Cave (A). Close-up of popcorn-like morphologies (B-D) where smooth calcite spherules protrude from a thicker stem (B). Dark biofilm cover the surface of many popcorn-like speleothems (B-C) though some speleothems appear uncovered (D). (E) Smooth calcite crusts with small drop-like calcite protrusions. Note the presence of dark biofilm on the surface. 


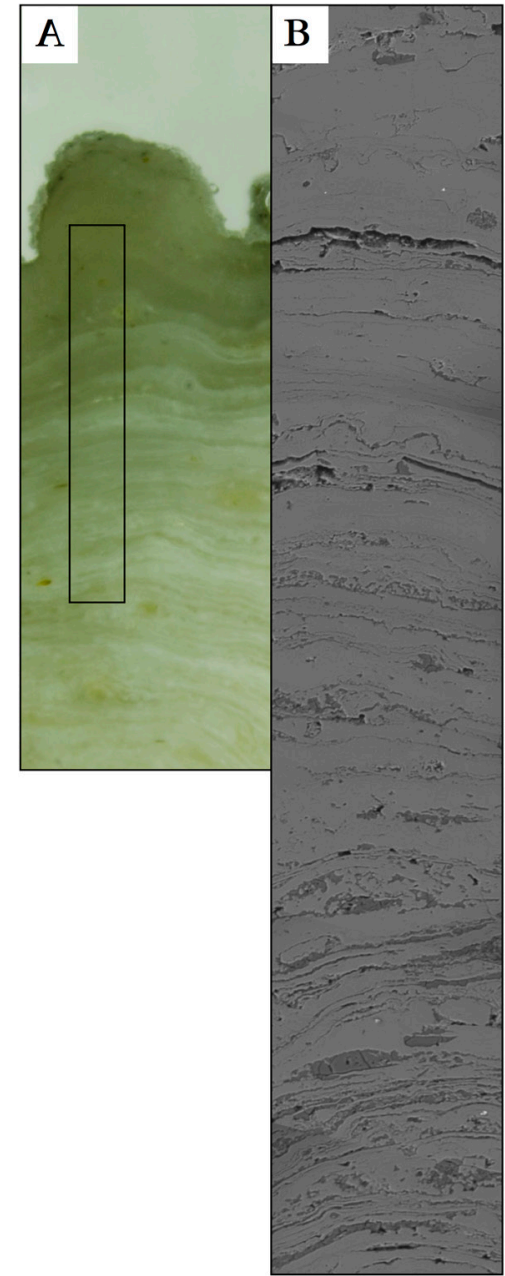

Fig. 4. (A) Optical stereomicrograph of coralloid speleothem in cross section along a vertical profile. (B) Vertical profile of a coralloid speleothem (indicated by the box) as seen with SEM. Note the stromatolite-like lamination and cyclic nature of the dark/lighter laminae.

general calcite matrix is characterized by the presence of groups of coccoids that are loosely attached to the edge of larger acicular calcite crystals like grapes on a vine (see Fig. 5F-G).

\section{Recent mycelium-like communities}

In contrast to the biofilm and its related biostructures, the speleothems are also covered in recent mycelium-like microbial communities (Fig. 6). These communities consist of interconnected hyphaelike filaments, $10-20 \mu \mathrm{m}$ in diameter and several $\mathrm{mm}$ in length (Fig. 6A-B). The filaments as seen in optical microscopy consist of various types mainly distinguished by coloration varying between green, pink and white (Fig. 6B-D). In ESEM the filaments dehydrate and become flat, and EDS analyses show that they mainly consist of $\mathrm{C}$, thus, they were live at sampling.

The recent mycelium-like communities appear to be a secondary colonization, which have a dual effect on the speleothems. In some cases, the filaments are incorporated into the speleothem fabric through rapid encrustation with calcite (Fig. 6E), which adds to the accretion of the calcite fabric. When the filaments are trapped and calcified, this affects the elemental composition, as well as the morphology of
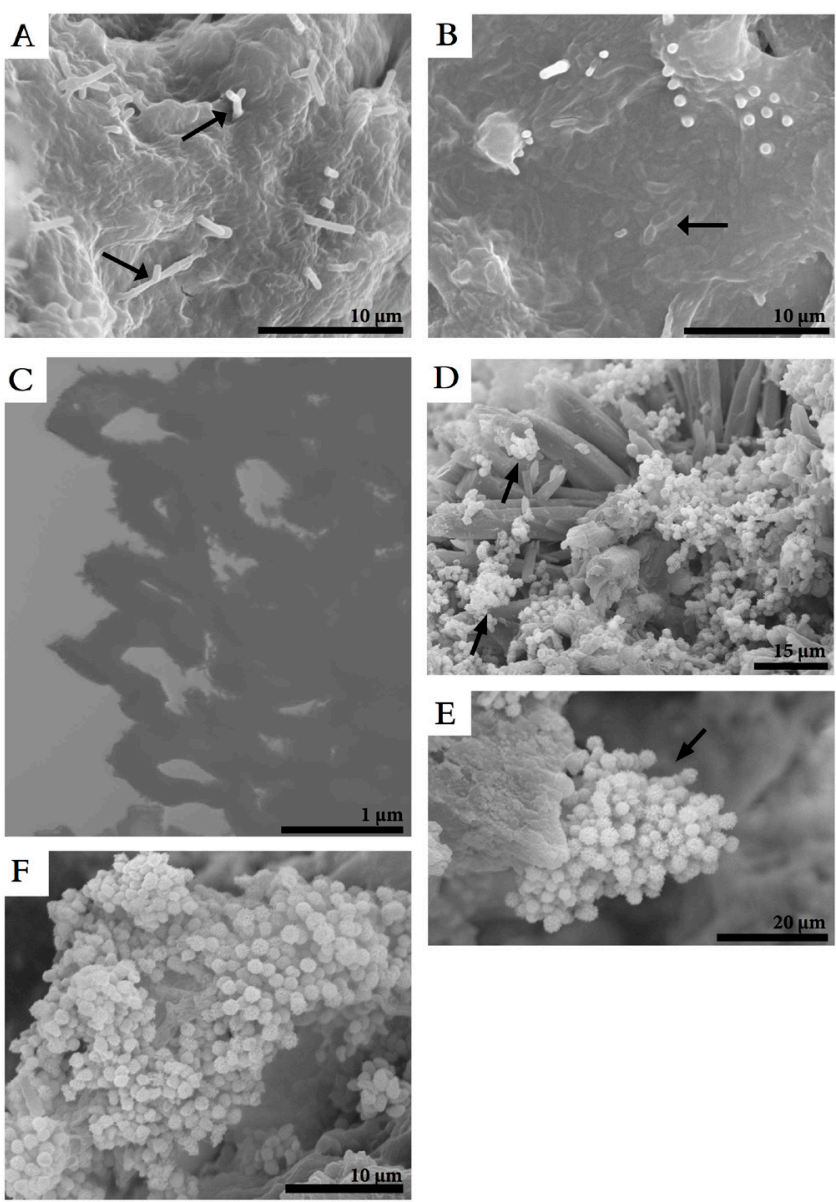

Fig. 5. Speleothem biofilm containing branching, septated filaments, spore-like coccoids, helically coiled filaments and EPS (A-F). (A) Scanning electron photomicrograph showing branching (arrows) microbial filaments imbedded in biofilm EPS. (B) Scanning electron photomicrograph of microbial filaments in EPS. Note segmentation among the filaments (arrow). (C) Photomicrograph of helically coiled filaments from a coral-like speleothem. (D-F) Photomicrographs of acicular calcite associated with abundant calcified coccoidal bodies. Note how the coccoids are situated in loose groups or aggregates on the top of acicular calcite crystals (arrows in D-E).

the calcite matrix. The hypha also appears to play a destructive role in speleothem genesis by actively etching the calcite or mechanically moving through, and enlarging, cracks in the fabric (e.g., Fig. 6F).

\section{Carbon isotopes}

Two of the speleothem samples were used for carbon isotope studies. The $\delta^{13} \mathrm{C}$ measurements of the calcium carbonate range between 9.0 and 11.0 , which suggest an inorganic source for the carbon (Sharp, 2007).

\section{Cave-wall biofilm}

The innermost ceiling, opposite to the part of the cave where most speleothems were sampled, is covered by an active biofilm. This biofilm is bright white when enlighted by flash lights and located to fractures in the dolerite where water is percolating (Fig. 7A). Optical microscopy and ESEM show that the biofilm is dominated by filaments, 1 to a few $\mu \mathrm{m}$ in thickness and tens of $\mu \mathrm{m}$ in length, coccoidal structures $\sim 10 \mu \mathrm{m}$ in diameter, and biofilm EPS with incorporated mineral fragments (Fig. 7B). The inorganic parts of the biofilm is dominated by carbonates that are presumed to 


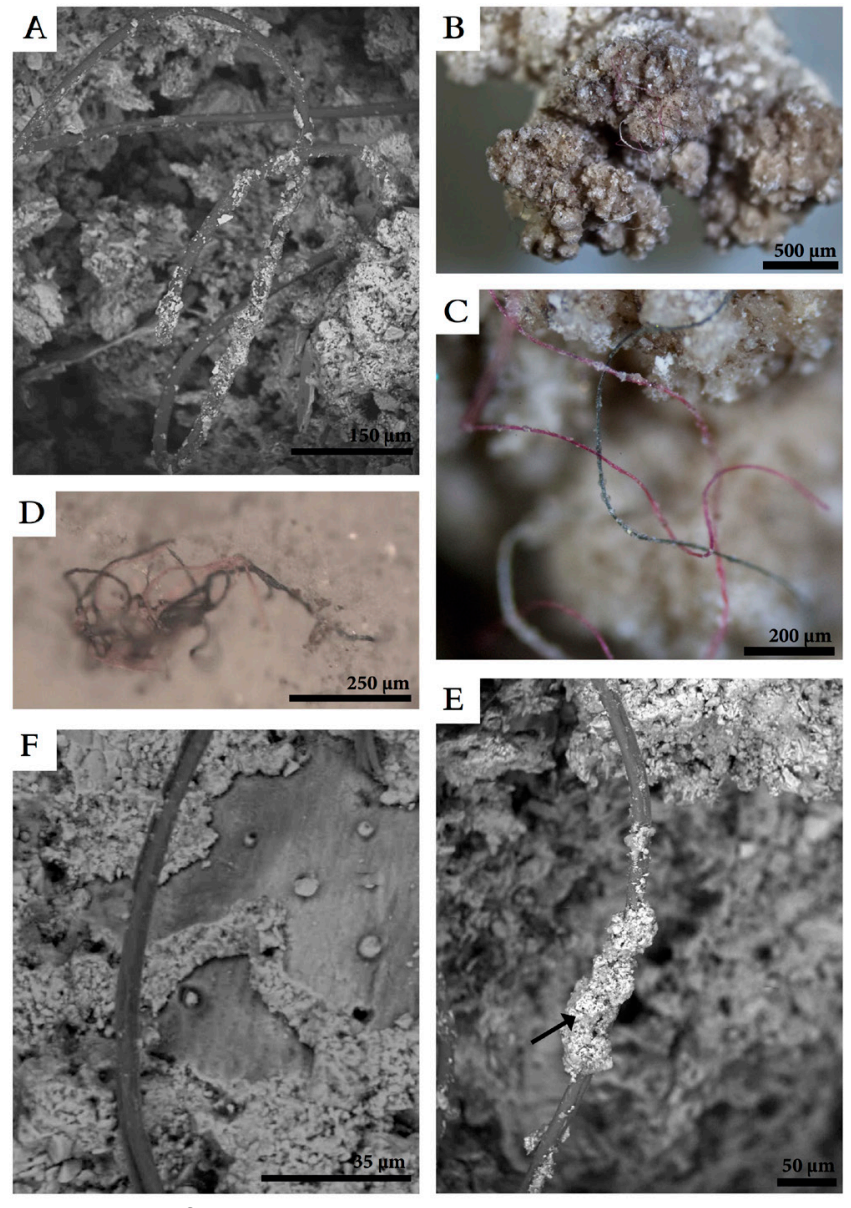

Fig. 6. Modern fungal communities associated with coral-like (A-E) speleothem and thin calcite crusts (F). (A) Photomicrograph of partly encrusted fungal hyphae associated with coral-like speleothems. (BD) Coralloids associated with fungal communities distinguished by their bright coloration of pink, green and white. (E) Scanning electron photomicrograph showing extensive encrustation of fungal hyphae with calcite (arrow). (F) chemical etching by fungal hyphae leave trails on smooth calcite crusts from Tjuv-Ante's Cave.

have precipitated within the biofilm, but dolerite rock fragments containing $\mathrm{Fe}, \mathrm{Si}, \mathrm{Al}, \mathrm{S}, \mathrm{Mg}, \mathrm{K}, \mathrm{Mn}$, and Ti are frequent. The EPS is dominated by $\mathrm{C}, \mathrm{P}$ and Ca with minor amounts of the previously mentioned elements.

Staining with the dye DyLight 488 NHS ester under fluorescent microscopy revealed septation among the filaments. It was also shown that the coccoidal structures are actually sacs with smaller, spore-like structures within (Fig. 7C-F). About 10-30 sporelike structures are contained in each sac, which are often found grouped together in loosely attached aggregates, not unlike the growth behavior of the calcified coccoids from speleothem biofilms (compare Fig. 7D-F to Fig. 5E-F).

\section{DISCUSSION}

\section{Microbiology of Tjuv-Ante's Cave}

Classifying microorganisms from their morphological traits is not preferable and should be combined with phylogenetic studies. However, the microbial morphologies of the speleothem biofilm and the cave wall communities are very characteristic and distinct. The morphologies characterized by repeated septated filaments, helically looped filaments, assemblages of spore-like structures and sacs with spores are all consistent with Actinobacteria-like morphologies (Miyadoh et al., 1997). Actinobacteria were once classified largely on their morphological traits and their morphologies are therefore better documented than those of many other prokaryotes. The morphological characteristics were considered so distinct that various taxa could be identified (Tresner et al., 1969). It has, however, been argued that such features are not indicative of their true taxonomic diversity and phylogenetic relationships (Goodfellow \& Williams, 1983), thus, we have not attempted to identify specific taxa.

It needs to be stressed that the biofilms on both the speleothems and the cave wall probably do not consist of Actinobacteria exclusively but various bacterial communities, which will be characterized in future molecular studies. However, according to the microbial morphologies Actinobacteria appear to be the dominating group of bacteria in the Tjuv-Ante's Cave.

Actinobacteria is one of the most commonly identified microbial groups in cave biofilms, speleothems and cave soils from all over the world and from various type
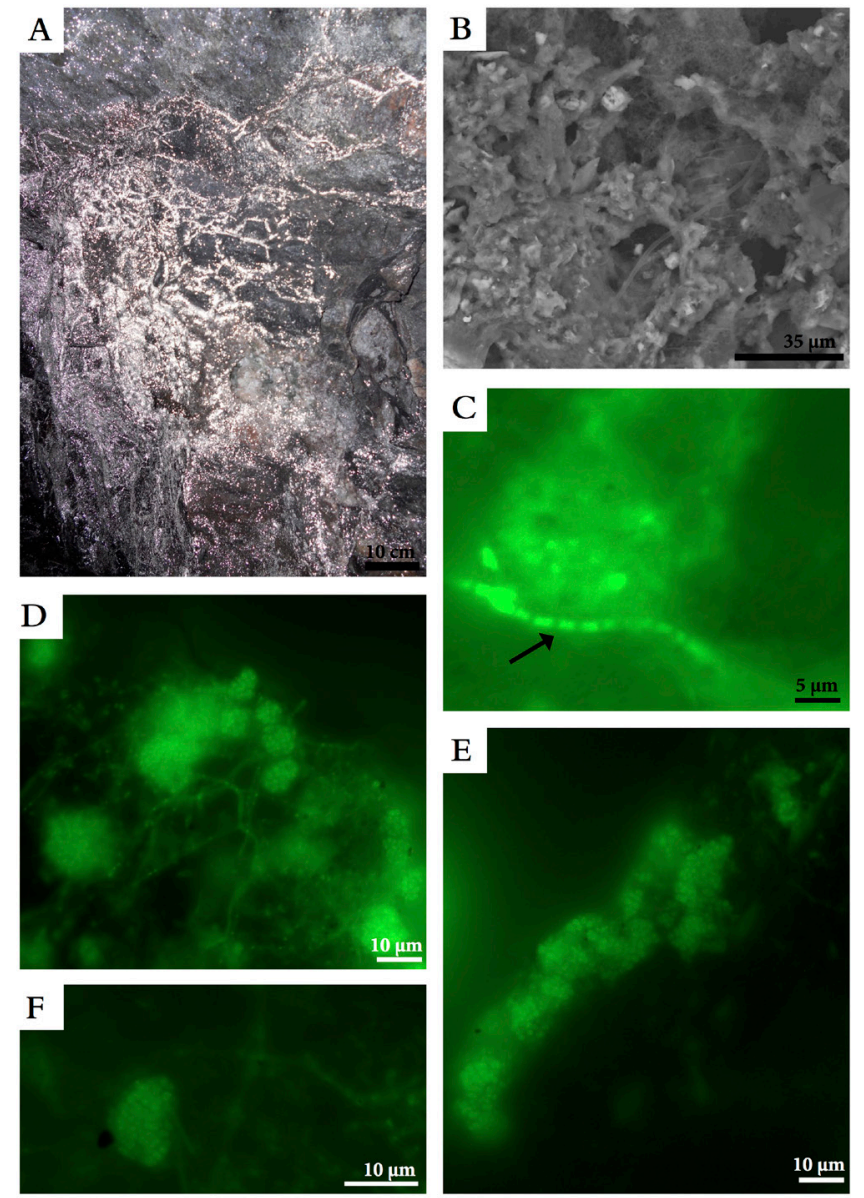

Fig. 7. Cave wall biofilm growing in cracks on the dolerite ceiling (where speleothems are absent or rare) (A-F). (A) Biofilm with a white glow (when lit by flashlight), note how the concentration of biofilm increases where there are cracks present in the rock. (B) Scanning electron photomicrograph of cave wall biofilm. Note the presence of filaments and thread-like EPS. (C-F) Micrograph of cave wall biofilm stained with the dye DyLight 488 ester and examined with fluorescence microscopy. Note the presence of narrow filaments and how larger sacs contain smaller spore-like objects. Note also how the sacs with spores are distributed; they are often found in groups not unlike the growth behavior of calcified coccoids from the speleothem biofilms. 
of caves including karsts, lava tunnels and granite caves (Groth et al., 1999; Jones, 2009; Northup et al., 2011; Vidal Romani et al., 2013). According to Groth and Saiz-Jiménez (1999) the dominance of Actinobacteria in caves may be due to two factors: low temperatures and high relative humidity. Most caves studied so far are characterized by stable temperatures ranging from $13^{\circ} \mathrm{C}$ to $15^{\circ} \mathrm{C}$ and high relative humidity (Groth et al., 1999 and references therein), thus, Actinobacteria are favored by the microclimates that prevail in caves. However, they are also dependent on the presence of available organic matter. Soils (including cave soils with high abundance of guano), the main ecological niche for Actinobacteria, are characterized by a high input of organic matter. In contrast, dripping water on stalactites and speleothems are characterized by inputs of relative low organic matter. However, Actinobacteria are known for their ability to grow on very poor media and to use recalcitrant organic matter such as lignocellulose, humic substances, etc., which presumably is the reason for their dominance in unfavorable environments with low nutrient supply like caves (Groth et al., 1999; Braissant et al., 2012). Growth patterns at low nutrients of Actinobacteria isolated from caves agree with cooperative growth patterns of bacterial colonies from low nutrient experiments (Ben-Jacob et al., 1994; Groth et al., 1999). They showed that bacteria develop sophisticated modes of cooperative behavior to cope with unfavorable conditions where aggregates of bacteria move in response to gradients in nutrient concentration. Thus, the overall microbial population of Tjuv-Ante's Cave appears to be heterotrophic. Chemoautotrophic communities might exist further in the fractures of the dolerite but there are no signs of them in the cave. Photosynthesis appears to be absent as well, which is consistent with the fact that the innermost part of Tjuv-Ante's Cave is situated beyond the twilight zone.

The localization of microbial communities in the fractures indicates that they are dependent on a steady fluid supply from within the dolerite. The fluids that percolate through the rock likely contain organic matter from the surface, accessible for the heterotrophic bacterial communities. The fungal community, which is also heterotrophic, could use both the organic matter from percolating fluids as well as the bacterial communities living on the speleothems as carbon sources.

The obvious dominance of biofilms and speleothems associated with the dolerite walls compared to the granite walls in Tjuv-Ante's Cave suggest that the composition of the rock and geochemistry of the percolating fluids (which is ultimately a result of the rock composition) influence the microbial colonization. Dolerite is of mafic composition with a high amount of reduced elements like Fe, Mn and S, all accessible energy sources for microorganisms. Thus, the geochemical prerequisites for chemoautotrophic endoliths exist but were not detected in the present study.

\section{Mineralogy of the speleothems}

Speleothems in granitic caves normally consist of opal-A (Vidal Romaní \& Vaqueiro Rodríguez, 2007; Vidal Romaní et al., 2010), just like speleothems in karsts and carbonate rocks mainly consist of carbonate minerals. Thus, the composition of the host rock greatly influences the composition of the speleothems. Tjuv-Ante's Cave is by definition a granite cave, however, the dolerite part is significant and influences both the geochemistry and biology in the cave. The speleothem and active biofilms are exclusively concentrated to the dolerite part of the cave and therefore, Tjuv-Ante's Cave is most related to volcanic caves with respect to authigenic minerals like calcite and Opal-A.

Dolerite is a plutonic rock equivalent in composition to basalt (which generally forms the volcanic tubes). The calcium content is quite high in dolerite compared to granite due to the high content of calcium-rich plagioclase, anorthite. Calcite is a common alteration mineral in mafic rocks, thus, it is not strange that calcite is a common mineral in speleothems and other secondary precipitates of volcanic caves (White, 2010). The mechanism of calcite speleothem formation in volcanic caves is the same as in limestone caves. Infiltrating rainwaters encounter the $\mathrm{CO}_{2}$-rich soil and dissolves $\mathrm{CO}_{2}$ to concentrations orders of magnitude greater than the atmospheric values. When acidic $\mathrm{CO}_{2}$-rich water reaches the limestone, a reaction occur and the limestone is dissolved. Those portions of the infiltration water that intersect an underlying cave passage is exposed to the lower $\mathrm{CO}_{2}$ pressure of the cave atmosphere and excess $\mathrm{CO}_{2}$ is degassed, thus supersaturating the drip water and forcing precipitation of $\mathrm{CaCO}_{3}$. This would work equally well in volcanic caves or a dolerite hosted cave like TjuvAnte's Cave, except that the source of calcium differs. Instead of limestone, the calcium in Tjuv-Ante's Cave is likely derived from the breakdown of anorthite, the more calcium-rich side of the plagioclase solid solution series in mafic rocks.

Anorthite is the least stable of the common mafic minerals. It breaks down roughly 100 times faster than the pyroxene minerals and 5000 times faster than olivine in contact with water (Lasaga, 1984). The calcium end-member of the plagioclase series breaks down roughly 100 times faster than the sodium end-member and several 1000 times faster than the orthoclase $\left(\mathrm{KAlSi}_{3} \mathrm{O}_{8}\right)$. The only difference between a limestone hosted cave and a mafic cave is the rate of dissolution, which is much slower in the latter.

\section{Microbial involvement in speleothem accretion}

The speleothems in Tjuv-Ante's Cave is highly influenced by the presence of microbes. Besides covering large parts of the speleothem surface, biofilms of Actinobacteria are incorporated within the darker silica-rich layers. These layers were probably deposited during periods of high microbial activity in the biofilms, thus, the concentric, stromatolitelike nature of the coral speleothems is assumed to represent seasonal growths of microbial biofilms. The biofilms were later mineralized and overgrown 
by calcite, thus, they appear to play a central role in accretion of the coralloid speleothems.

The other speleothem types, popcorn-like speleothems and thin calcite crusts (flowstone), are probably variations of the coralloid speleothems with respect to growth and degradation. Tjuv-Ante's Cave seems to represent an active system where coralloid speleothems, mainly accreted through seasonal, episodic mineralization of $\mathrm{C}, \mathrm{Mg}$ and Si-rich biofilms, go through varying stages of formation-degradation cycles, where the end-stages are represented by the thinning calcite crusts, in which fungal etching trails and cracking are particularly apparent.

The calcite component of the speleothems appears less influenced by microorganisms than the silica-rich layers. Only few microfossils are found in the calcite layers and no organic $\mathrm{C}$ appears to be present. The carbon isotopes indicate that the calcium carbonate is abiotically formed and not influenced by microbial metabolism. We hypothesize that these calcium carbonate layers have been deposited during seasons with low or no biological activity, but in a situation where fluid water is available.

It further seems as though the fungal presence is important for the development of speleothems in Tjuv-Ante's Cave. Their dual role as constructive and destructive forces on the speleothem can be seen when comparing the three morphotypes of speleothems present in Tjuv-Ante's Cave. The coralloid speleothems and to some extent, the popcorn-like speleothems, appear to be actively growing and incorporate fungal hyphae into the overall fabric through rapid precipitation of calcite atop of fungal filaments (Fig. 6E). On the other hand, in the eroded speleothems the presence of fungal hyphae seem to have a degrading effect on the fabrics because of fungal calcite etching. The erosional effect of fungal biofilms suggests that the longevity of these kinds of speleothems may be limited in the rock record. This is indeed supported by the relatively young age of the speleothems (1259 \pm 30 years B.P), which was derived from the $\mathrm{C}-14$ dating.

\section{CONCLUSIONS}

- Host rock composition greatly influences the formation of speleothems in Tjuv-Ante's Cave, including mineralogy, geochemistry and microbial colonization.

- Biofilms are highly involved in the formation of speleothems: remnants of Actinobacteriadominated communities and spore-like coccoids are preserved within the organic layers of the speleothems.

- The speleothems have accreted in cycles and are stromatolitic in nature. Dark, organicrich opal-A/biofilm layers alternate with light colored calcite layers where the organic-rich layers are presumed to represent conditions of extensive microbial growth in the cave during spring/summer seasons while the inorganic layers represent accretion of the speleothems during winter or early spring. While speleothem biofilms add to the build- up of the speleothems, the modern fungal communities mainly have a destructive role on the speleothem fabric. This interplay between accreting and destructive forces on the speleothems ultimately results in the three morphological types identified in Tjuv-Ante's Cave; well-developed coralloids, smooth popcorn-like speleothems and calcite crusts. This is also consistent with the younger age of the speleothems, as compared to that of the cave.

- The modern cave wall biofilms have a similar composition as the calcified speleothem biofilms, with thin filaments and spore-like coccoids as the main biofilm-communities. We suggest that these biofilms represent early stages of speleothem formation, or at least potential sites for the formation of speleothems in Tjuv-Ante's Cave.

\section{ACKNOWLEDGEMENT}

The speleothems were collected in a Nature Reserve and Natura 2000 Site, with permission from the County Government Länsstyrelsen Västerbotten (permission 521-6864-2010). The authors would like to thank Marianne Ahlbom at the Department of Geological Sciences (DOGS), Stockholm University, for help with the ESEM/EDS analyses. We would also like to thank Heike Siegmund at DOGS for stable isotope $\left(\delta^{13} \mathrm{C}\right)$ analyses and we thank the Imaging Facility at Stockholm University (IFSU) for support with microscopy. This work was funded by the Swedish National Space Board (Contract No. 83/10), Swedish Research Council (20124364) and the Danish National Research Foundation (DNRF53). Finally, the manuscript was improved by the suggestions and comments of three anonymous reviewers, for which we are grateful.

\section{REFERENCES}

Arp G., Reimer A. \& Reitner J., 1999a - Calcification in cyanobacterial biofilms of alkaline salt lakes. European Journal of Physiology, 34: 393-403. http://dx.doi.org/10.1080/09670269910001736452

Arp G., Reimer A. \& Reitner J., 2001 - Photosynthesisinduced biofilm calcification and calcium concentrations in Phanerozoic oceans. Science, 292: 1701-1704. http://dx.doi.org/10.1126/science.1057204

Arp G., Thiel V., Reimer A., Michaelis W. \& Reitner J., $1999 \mathrm{~b}$ - Biofilm exopolymers controls microbialite formation at thermal springs discharging into the alkaline Pyramid Lake, Nevada, USA. Sedimentary Geology, 126: 159-176.

http://dx.doi.org/10.1016/S0037-0738(99)00038-X

Barton H.A. \& Northup D.E., 2007 - Geomicrobiology in cave environments: past, current and future perspectives. Journal of Cave and Karst Studies, 69: 163-178.

Barton H.A., Spear J.R. \& Pace N.R., 2001 - Microbial life in the underworld: biogenicity in secondary mineral formations. Geomicrobiology Journal, 18: 359-368. http://dx.doi.org/10.1080/01490450152467840

Baskar S., Baskar R., Lee N. \& Theophilus P.K., 2009 - Speleothems from Mawsmai and Krem Phyllut caves, Meghalaya, India: some evidences on biogenic activities. Environmental Geology, 57: 1169-1186. http://dx.doi.org/10.1007/s00254-008-1413-y 
Ben-Jacob E., Schochet O., Tenenbaum A., Cohen I., Czirók A. \& Vicsek T., 1994 - Generic modeling of cooperative growth patterns in bacterial colonies. Nature, 368: 46-49. http://dx.doi.org/10.1038/368046a0

Berglund M., 2012 - The highest postglacial shore levels and glacio-isostatic uplift pattern in northern Sweden. Geografiska Annaler, Series A Physical Geography, 94: 321-337.

http://dx.doi.org/10.1111/j.1468-0459.2011.00443.x Braissant O., Bindschedler S., Daniels A.U., Verrecchia E.P. \& Cailleau G., 2012 - Microbiological activities in moonmilk monitored using isothermal microcalorimetry (Cave of Vers chez le Brandt, Neuchatel, Switzerland). Journal of Cave and Karst Studies, 74: 116-126.

http://dx.doi.org/10.4311/2011JCKS0213

Braissant O., Decho A.W., Dupraz C., Glunk C., Przekop K.M. \& Visscher P.T., 2007 - Exopolymeric substances of sulfate-reducing bacteria: interactions with calcium at alkaline $\mathrm{pH}$ and implication for formation of carbonate minerals. Geobiology, 5: 401-411.

http://dx.doi.org/10.1111/j.1472-4669.2007.00117.x

Curry M.D, Boston P.J., Spilde M.N., Baichtal J.F. \& Campbell A.R., 2009 - Cottonballs, a unique subaqeous moonmilk, and abundant subaerial moonmilk in Cataract Cave, Tongass National Forest, Alaska. International Journal of Speleology, 38: 111-128.

http://dx.doi.org/10.5038/1827-806X.38.2.3

Dupraz C. \& Visscher P.T., 2005 - Microbial lithification in marine stromatolites and hypersaline mats. Trends in Microbiology, 13: 249-438.

http://dx.doi.org/10.1016/j.tim.2005.07.008

Dupraz C., Reid R.P., Braissant O., Decho A.W. Norman, R.S \& Visscher P.T., 2009 - Processes of carbonate precipitation in modern microbial mats. Earth Science Reviews, 96: 141-162. http://dx.doi.org/10.1016/j.earscirev.2008.10.005

Goodfellow M. \& Williams S.T., 1983 - Ecology of acinomycetes. Annual Reviews in Microbiology, 37: 189-216.

http://dx.doi.org/10.1146/annurev.mi.37.100183.001201

Groth I. \& Saiz-Jiménez C., 1999 - Actinomycetes in hypogean environments. Geomicrobiology Journal, 16: 1-8. http://dx.doi.org/10.1080/014904599270703

Groth I., Vettermann R., Schuetze B., Schumann P. \& Saiz-Jiménez C., 1999 - Actinomycetes in karstic caves of Northern Spain (Altamira and Tito Bustillo). Journal of Microbiological Methods, 36: 115-122.

http://dx.doi.org/10.1016/S0167-7012(99)00016-0

Gysi A.P. \& Stefánsson A., 2012a - Experiments and geochemical modeling of $\mathrm{CO}_{2}$ sequestration during hydrothermal basalt alteration. Chemical Geology, 306-307: 10-28.

http://dx.doi.org/10.1016/j.chemgeo.2012.02.016

Gysi A.P. \& Stefánsson A., 2012b - $\mathrm{CO}_{2}$-waterbasalt interaction. Low temperature experiments and implications for $\mathrm{CO}_{2}$ sequestration into basalts. Geochimica et Cosmochimica Acta, 81: 129-152. http://dx.doi.org/10.1016/i.gca.2011.12.012

Hövelmann J., Austrheim H. \& Jamtveit B., 2012 Microstructure and porosity evolution during experimental carbonation of a natural peridotite. Chemical Geology, 334: 254-265. http://dx.doi.org/10.1016/j.chemgeo.2012.10.025

Jones B. 2001 - Microbial activity in caves - a geological perspective. Geomicrobiology Journal, 18: 345-357. http://dx.doi.org/10.1080/01490450152467831

Jones B., 2009 - Phosphatic precipitates associated with actinomycetes in speleothems from Grand Cayman, British West Indies. Sedimentary Geology, 219: 302-317. http://dx.doi.org/10.1016/j.sedgeo.2009.05.020
Lasaga A.C., 1984 - Chemical kinetics of water-rock interactions. Journal of Geophysical Research, 89: 40094025. http://dx.doi.org/10.1029/JB089iB06p04009

Miyadoh S., Tsuchizaki N., Ishikawa J. \& Hotta K., 1997 - Digital Atlas of Actinomycetes. Tokyo, Japan, Society for Actinomycetes Japan. Akasura Publication, p. 244.

Northup D.E., Melim L.A., Spilde M.N., Hathaway J.J.M., Garcia M.G., Moya M., Stone F.D., Boston P.J., Dapkevicius M.L.N.E. \& Riquelme C., 2011 - Lava cave microbial communities within mats and secondary mineral deposits: implications for life detection on other planets. Astrobiology, 11: 601-618.

http://dx.doi.org/10.1089/ast.2010.0562

Oskierski H.C., Dlugogorski B.Z. \& Jacobsen G., 2013 - Sequestration of atmospheric $\mathrm{CO}_{2}$ in a weatheringderived, serpentinite-hosted magnesite deposit: ${ }^{14} \mathrm{C}$ tracing of carbon sources and age constraints for a refined genetic model. Geochimica et Cosmochimica Acta, 122: 226-246.

http://dx.doi.org/10.1016/j.gca.2013.08.029

Schwarzenbach E.M., Früh-Green G.L., Bernasconi S. M., Alt J.C. \& Plas A., 2013 - Serpentinization and carbon sequestration: a study of two ancient peridotite-hosted hydrothermal systems. Chemical Geology, 351: 115-133. http://dx.doi.org/10.1016/j.chemgeo.2013.05.016

Sharp Z., 2007 - Principles of stable isotope geochemistry. Pearson Education, Upper Saddle River.

Sjöberg R., 1981 - Tunnelcaves in Swedish Archean Rocks. Transactions of the British Cave Research Association, 8: 159-167.

Sjöberg R., 1982 - Tunnelgrottor $i$ södra västerbotten: morfografiska och morfogenetiska studier. Gerum Geografiska Rapporter A:31. 93 p.

Sjöberg R., 1994 - Tunnel-caves in Sweden: morphological and morphogenetic studies. Svenska grottor, 8: 1-42.

SMHI, 2012 - Klimatdata, http://www.smhi.se/ klimatdata (visited 2012-12-13).

Tresner H.D., Davies M.C. \& Backus E.J., 1969 - Electron microscopy of Streptomycetes spore morphology and its role in species differentiation. Journal of Bacteriology, 81: 70-80.

Van Noort R., Spiers C.J., Drury M.R. \& Kandianis M.T., 2013 - Peridotite dissolution and carbonation rates at fracture surfaces under conditions relevant for in situ mineralization of $\mathrm{CO}_{2}$. Geochimica et Cosmochimica Acta, 106: 1-24.

http://dx.doi.org/10.1016/j.gca.2012.12.001

Vidal Romaní J.R. \& Vaqueiro M., 2007 - Types of granite cavities and associated speleothems: genesis and evolution. Nature Conservation, 63: 41-46.

Vidal Romaní J.R., Sanjurjo Sánchez J., Vaqueiro M. \& Fernández Mosquera D., 2010 - Speleothems of granite caves. Comunicações Geológicas, 97: 71-80.

Vidal-Romaní J.R., Sanjurjo-Sánchez J., Vaqueiro Rodríguez M., González-López L. \& López-Galindo M.J., 2013 - Speleothems in cavities developed in magmatic rocks. International Congress of Speleology Proceedings 3: 479-482.

White W.B., 2010 - Secondary mineral in volcanic caves: data from Hawai'i. Journal of Cave and Karst Studies, 72: 75-85.

http://dx.doi.org/10.4311/jcks2009es0080

Woo K.S., Choi D.W. \& Lee K.C., 2008 - Silicification of cave corals from some lava tube caves in the Jeju Island, Korea: implications for speleogenesis and a proxy for paleoenvironmental change during the Late Quaternary. Quaternary International, 176-177: 82-95.

http://dx.doi.org/10.1016/j.quaint.2007.05.008 